\title{
APPROACHES TO APPROACHING THE NEIGHBOR ${ }^{1}$
}

This Dossier collects seven essays which examine the possibilities and the limitations of the precept "Love your neighbor as yourself", a precept that is central to both Hebrew and Christian doctrines and teachings, and that also transcends religiosity as it is crucial in both secular and even "postsecular" thinking and praxes.

The first essay in this dossier, "Amor al vecino y cuestionamientos a la nación en la literatura del siglo diecinueve", surveys passages by thinkers Hannah Arendt, Zygmunt Bauman, Maurice Blanchot, Judith Butler, Roberto Esposito, Sigmund Freud, Ernesto Laclau, Emmanuel Levinas, Kenneth Reinhard, Franz Rosenzweig, Eric Santner, Richard Sennett and Slavoj Žižek, among others, sampling some positions in the debate about the practicality of the precept "Love your neighbor as yourself". For the aforementioned thinkers, the very figure of the neighbor in itself is interesting, as it lies beyond the binary opposition formed by friend and enemy, or by that person I identify with, on the one hand, and that complete stranger I may see as an irreducible Other, on the other. The neighbor, as a figure that does not belong to the immediate private space of the familial and domestic circle but who is still within the circle of physical proximity in the community, is relevant for political and for ethical reasons. And whereas the precept to love the neighbor as one loves oneself may indeed be an impractical, uncomfortable, irritating and even unfeasible command, the truth is that it may also be productive as an ideal that many aspire to live up to. This ideal may bring out the best qualities in us and in some cases may even be the ultimate proof not just of our humaneness but also of our humanity.

The applicability and implementability of the precept "Love your neighbor as yourself", however, are far from unproblematic for seven, if not more, main reasons:

\footnotetext{
${ }^{1}$ This dossier results from research undertaken within the Project "Literatura y comunidades: una visión desde el género" (FEM 2011-23808, Ministerio de Economía y Competitividad), whose Main Researcher is Prof. Marta Segarra, Centre Dona i Literatura, Universitat de Barcelona.
} 
-the precept does not specify whether loving the neighbor involves loving him or her in his or her reality - and alterity - or appropriating the neighbor in an attempt to assimilate him or her to, and within, our own reality.

-the precept does not specify whether its beneficiary is the specific neighbor -in his/her corpo-reality - or the self, who gains by the occasion or by the gesture of loving him or her. Or, in other words, the precept does not specify whether, in loving the neighbor, we are loving the actual neighbor or we are loving loving the neighbor, as he/she may be the manifestation of the existence of God or of an ethical sense. In that case, by obeying the precept we may be paradoxically ignoring the actuality of the neighbor in our act of loving him/her.

-the very fact that the precept is an absolute command is also problematic, as it is an obligation to do what we are told to do. Our compliance to it, as part of the ideology in which we live, may in fact be depriving us of our agency in choosing to obey the precept or not, and may even turn us into irresponsible, rather than responsible, subjects.

-the precept may be inherently negative, as it may be based on our awareness of human vulnerability and precariousness and of our - and our neighbor's - mortality. As a result of this awareness, loving the neighbor as one does oneself can be ultimately based on fear, rather than on a more positive affect.

-the precept does not specify who we should consider a neighbor, how close the neighbor must be to deserve our love, or whether we should love the neighbor and not love that person who is not a neighbor. What degree of physical or cultural proximity are we considering here and why should we limit our ethical concern, denying thus the same rights to those who are outside the scope of what we understand is our neighborhood or community?

-the precept seems to fix the neighbor as the recipient of our love, but it does not contemplate him/her as agent him/herself or as somebody who is not only in a one-to-one relation with us, but who is embedded within a community with/in which he/she interacts too.

-the precept is double: it requires that I love my neighbor as myself, so it demands self-love too. Whereas we often take self-love for granted and as an unproblematic given, Zygmunt Bauman reminds us that certain conditions have to be met for self-love to happen.

Loving one's neighbor as oneself is, therefore, such a complicated idea that when/if it is honored and implemented unproblematically, it becomes almost nothing short of a miracle. The six essays that follow the theoretical opening to the dossier are written in four different languages (English, Spanish, French and Catalan) and deal with literary representations of the (im)possibilities of the precept in the context of specific social frameworks in geocultural areas as varied as New England, the Southern United States, Ecuador, Spain, France and Russia. 
The dossier focuses on the intimate connection between subject-familycommunity, on the one hand, and the new nation-states that fed/were fed by the concept of "national community" resulting from different romantic nationalistic identitarian movements, especially in Euro-America, in the nineteenth century. If, as Benedict Anderson points out, the nation-state is imagined as "limited", as "sovereign" and as a "community" with an enduring and far-reaching past, it is necessary to ask what subjects are considered part of that imaginary, and which subjects are excluded in those nation-constructing processes. The nineteenth century witnessed, in unprecedented ways, the shifting of populations from rural to urban areas, and from impoverished regions and countries to more prosperous nations and continents. These phenomena resulted in "local" or "native" subjects feeling uncomfortable at being circumstantially exposed to, and forced to cohabit with, new neighbors whose origins, languages, traditions and ways of functioning were unknown or even the sources of fear. That century is, therefore, rich territory to analyze whether - then and now - the neighbor was/is considered somebody who deserves our love within the community or rather a strange subject who does not deserve our love as he/she does not belong to our familiar and/or national space. Did the figure of the neighbor in the nineteenth century expand the circle of one's responsibility until it reached the stranger - and even the foreigner - or did his/her alterity turn him/her into unassimilable, and intrinsically unlovable, to one's eyes? In responding to these questions, all six contributions treat the neighbor not as an abstract figure, but in the specificity of his/her corpo-reality, in/with its valences of sex, gender, and sexuality, and of ethnicity, religion and, above all, social class.

In the second essay, "Melville's Carnival Neighborhood", Wyn Kelley analyses the relationship between Herman Melville and Nathaniel Hawthorne who, in the years 1850 and 1851, lived relatively close to each other in the Berkshires, Massachusetts. Their friendship was influenced by their neighbor Sarah Morewood, a woman whose festive, carnivalesque and even subversive spirit may have conferred new possibilities of freedom and fluidity on Melville's friendship with Hawthorne and on his own personal literary project.

In the third essay, "Dressing Uncivil Neighbor(Hood)s. Walt Whitman's Adhesive Democracy in 'Calamus' and 'Drum-Taps", Laura López highlights the continuity between these two collections of poems written before and after the American Civil War. For López, Whitman conceives "adhesiveness", love and eroticism between men, as the vehicle for a true social democracy that will help heal the divisions between neighbors, North and South, in the United States.

In the fourth essay, "Literatura y coexistencia indígena en los Andes: 'Incómoda' vecindad de Dolores Veintimilla”, Diego Falconí Trávez argues that in her texts Dolores Veintimilla imagines the Ecuadorian community as a space of citizenship and neighborhood that includes both the indigenous peoples and Creole women. She thus reinscribes them conceptually at the center of the 
political and cultural system of what should be an Ecuadorian national imagery that responds to the true heterogeneity of the Andean sociopolitical reality.

In the fifth essay, "Misery, Hope and Humanity in Benito Pérez Galdós' Misericordia (1897)", María Isabel Rovira Martínez de Contrasta analyzes the relationships between a servant and a street beggar in that novel. Rovira suggests that Galdós, who had lost faith in the regenerative powers of the Spanish political, economic and educational institutions of the nineteenth century, still believed in the redemptive power of human goodness, generosity and loyalty, and in the possibilities of the caring bonds between two neighbors of different nationality, ethnicity, language, sex and religion.

In the sixth essay, "Flora Tristan: De la nécessité de faire bon accueil aux femmes étrangères" Martine Reid studies the life and works of Flora Tristan, a woman who travelled alone both in Europe and across the Atlantic ocean, to Latin America, in the first half of the nineteenth century, and who subsequently actively fought for those "foreign" women who found themselves traveling alone in France. Tristan helped those "neighbors" in need, understanding "neighbor" to be as much the national subject as the subject in transit, the immigrant without documents, the refugee.

In the last essay, "L'abisme en els confins d'Europa: la Rússia de Dostoievski", Carlota Surós analyses the "neighborhood" between Russia and the West, and also within Russia, in cities such as Saint Petersburg, between the artificially Europeanized elite and the Russian people. For Surós, Dostoievski proposes returning to a community that believes in collective progress and that aims to meet our/one's obligations to others through the concepts of neighborly love and of kenosis.

All the literary texts analyzed in this dossier challenge the traditional identification of the "national subject" with the heteropatriarchal "pure" or "neutral" subject. And in all these literary texts, the traditional definitions of "neighbor", "national subject" and "nation" are expanded and incorporate women, the indigenous peoples, the foreign and the foreigner, the person in transit, the dispossessed, the beggar, the refugee, all those subjects often regarded as not worthy of our neighborliness and maybe, because of this, considered less, or even not at all, loveable.

RODRIGO ANDRÉS

Universitat de Barcelona

14 